\title{
Actualizing Reader-Response Theory on L2 Teacher Training Programs
}

\section{Gary Harfitt and Blanche Chu}

In this article we share our experiences of using poems in teacher-training courses where the students are predominantly second-language learners. We describe how we tried to help learners engage with a creative text through its language and meaning. We share our experiences of helping to facilitate the open expression of opinions and feelings in L2 teachers (both inservice and preservice) on creative texts, specifically the poem "My Papa's Waltz" by Theodore Roethke. The use of this poem and others like it in teacher education courses in three of Hong Kong's tertiary institutions has produced consistently impressive outcomes in terms of teachers' responses to poetry in general. We aim to illustrate a teaching strategy that emphasizes the reader as expert and to show how this process leads EFL/ESL teachers as well as English-language learners (ELLs) to experience more lived, esthetic responses as part of their coursework.

Dans cet article, nous partageons des expériences où nous avons employé des poèmes dans des cours de formation d'enseignants avec des étudiants qui étaient surtout apprenants en langue seconde. Nous décrivons nos efforts pour intéresser les étudiants à un texte littéraire par la langue et le sens. Nous évoquons nos expériences où nous avons aidé des enseignants (en service et en stages) de langue seconde à ouvertement exprimer leur avis et leurs sentiments par rapport à des textes littéraires, notamment le poème "My Papa's Waltz » de Theodore Roethke. L'emploi de ce poème et de d'autres du même genre dans les cours de formation d'enseignants dans trois institutions d'études supérieures à Hong Kong a systématiquement généré des résultats impressionnants relatifs à la réaction des enseignants face à la poésie de façon générale. Nous tenons à illustrer une stratégie d'enseignement qui met l'accent sur le lecteur comme expert pour ensuite démontrer comment ce processus aide les enseignants en ALP et ALS, ainsi que les apprenants d'anglais à réagir de façon plus spontanée et esthétique dans leurs cours.

\section{Introduction and Background}

In this article we outline the incorporation of a reader-response lesson that has developed into a fundamental part of a teacher training course on how to teach literature and language arts in the Hong Kong context. It is a response to curriculum changes that represent a major shift in emphasis in how 
the English-language curriculum is being taught. First, in 2009 a three-year senior secondary academic structure began at the secondary 4 level (grade 10). The course developers' overarching aim was for learners to develop their capacity for critical thinking, creativity, self-expression, personal growth, empathy, and cultural understanding. One way to achieve this is by including optional elective subjects that include language arts elements such as the study of short stories, poems, and songs. In official documents explaining the rationale for using literary texts in the secondary structure, there are also references to the promotion of creativity in learners so that they might formulate and express informed and imaginative views and responses (Curriculum Development Council, 2007). This is a welcome move to many educators, as it gives teachers an opportunity to incorporate a range of creative texts and materials into their teaching of English; in essence, it places literary texts at the heart of the language curriculum in Hong Kong.

Yet inevitably, obstacles to this reform arise. The greatest concern that will be recognized by all teachers of English-language learners (ELLs) is the linguistic challenge presented by literary texts, especially poems. This has been recognized in many EFL and ESL contexts (Carlisle, 2000; Elliott, 1990). There are also questions of how much emphasis to place on the language of the poem and on knowing what the poem means, two issues that often prevent the enjoyment of poems and other creative texts. To some learners and educators, the more measurable micro-analysis of literary processes (e.g., vocabulary) is seen as more important than the promotion of esthetic responses. We accept that there is tension between emphasis on meaning and emphasis on language when studying a poem in class. We see the difficulties inherent in the proposed scheme of work for the senior secondary elective on poems and songs, where reformers recommend that teachers encourage their students to express their personal views and feelings freely in response to poems and songs. As many teacher educators will acknowledge, if ELLs are unfamiliar with the language in a poem, then they will find it difficult to comprehend the meaning, which in turn prevents them from sharing their personal views and opinions.

It has been said that literary texts now have greater prominence in the process of second-language acquisition and that "there is no single 'correct' way of analyzing and interpreting the text, nor any single correct approach" (Carter, 2007, p. 10). This is also at odds with what we know about ELLs, many of whom fear losing face if their answer or viewpoint is perceived as "wrong" or "silly" by teachers or peers. Indeed, the face issue underlines the importance of cultural knowledge when teaching ELLs. Students may well have valuable feelings to share, but whether they have the confidence to express them freely through this new curriculum change, as the authorities hope, is debatable. Students often fear making mistakes in front of others (Horwitz, Horwitz, \& Cope, 1986) and of receiving negative feedback from 
their teachers, and this has specific reference to Hong Kong (Tsui, 1996), where learners' anxiety can inhibit learning and reduce opportunities for classroom interaction. This suggests that asking students to share personal responses to poetry is not as easy as it looks from the perspective of either the teacher or the learner. This was of primary concern to us as we looked at poems for our teacher training courses.

Finally, a local barrier is our teachers' perceived lack of expertise in the area of literature. Most English-language teachers in Hong Kong have not enjoyed an academic background that involves the study of literature per se. Neither have local teacher training courses included literature as an integral part of pedagogy and methodology courses; most have chosen instead to offer student teachers a minor course as an optional elective. Although specially arranged government-funded courses on the teaching of literature and language arts have been offered, many teachers still feel unprepared and understandably apprehensive about using literary texts in their classrooms. We asked inservice teachers how they felt about the implementation of literature and language arts into the curriculum, and the following responses were fairly representative.

I haven't studied literature before, so how am I going to answer questions from students?

Most of the time I don't understand what the poem and poet is saying. It's all too abstract.

I like literature, but I wouldn't know how to choose the right poem for class. My students want to know every meaning and answer, but many poems don't have an answer!

This was the context we faced when designing teacher training courses for teachers on how to use poems in class. How could we overcome the inevitable linguistic obstacles in a poem while encouraging students to engage with the text and to respond to it personally without worrying about getting the "right" answer, which is a common concern in Hong Kong's examination-oriented culture? In sum, we sought active student engagement with both language and meaning in a poem (Showalter, 2003). Thus we had not only a linguistic, but also a sociocultural focus. We attempted to present activities that would allow students to engage with a poem on a personal level at first and then as a group, while also ensuring that we did not impose the meaning of the poem on students from our own position as course lecturers.

\section{Tackling the Problems with Reader-Response Theory}

We wanted our student teachers not simply to give a lecture on theories and beliefs, but to see first-hand how readers' response can highlight the creative 
role of a reader. We needed a text that would allow teachers in our class to see this process for themselves. It is important here to explain the criteria for choosing poems in our course. We believed that texts that had a greater potential for provoking varied responses in readers would be most suitable. To achieve this, we looked at poems that also acted as narratives or stories in which students could predict what was happening (e.g., "My Papa's Waltz" by Theodore Roethke, "Housewife" by Angela Readman, and "Growing Pains" by Jean Little). These texts tended to have universal themes such as relationships, which we hoped our adult students would find more motivating than those of other poems that might lack a shared context.

We were conscious of the views of Rosenblatt $(1938,1978)$, who famously coined the terms efferent and esthetic to distinguish between two contrasting ways of experiencing a text. In the former, Rosenblatt argues that readers take a pragmatic approach to the text, acquiring information and achieving basic comprehension. In the esthetic approach, readers respond to their own unique experience with the text; in other words, they engage with the text. Rosenblatt urged a reconsideration of how literature should be approached in the classroom so that teachers and students would no longer be concerned solely with identifying the "correct" interpretation in texts. It is true that Rosenblatt did not have EFL/ESL issues as her primary focus, and we can see why her voice may appeal more to a native-speaker English/language arts teaching and learning community, but we were also conscious that scholars like Hirvela (1996), Karolides (1999), and Carlisle (2000) had been able to connect the concept of reader-response to the EFL/ESL arena. So we were keen to build on this foundation in order to show that readers' response can be a valid teaching approach in the EFL/ESL classroom.

At the start of our courses, our teacher-learners had been asked to write about their views on poetry and the use of poems in class, and these responses echoed Rosenblatt's (1978) definition of an efferent approach. Teachers said that they needed to know the meaning of a poem and the words before teaching it to their own students, in line with Carlisle's (2000) view that EFL readers see texts as lengthy comprehension exercises. In our teacher-training courses, we also aimed to have teachers experience readers' response and not just hear or read about others' interpretations (even though this may have been the preferred learning style of many!). We wanted the teachers to discover that their own interpretations carried authority too and in so doing to reinforce this as a potential pedagogical practice in their own L2 classrooms.

\section{Using the Poem "My Papa's Waltz"}

In the light of our teachers' responses, Roethke's "My Papa's Waltz" (www.poemhunter.com) seemed to fit perfectly with what we wished to achieve. Written more than half a century ago in the United States, the poem is controversial because it often conjures up two contrasting reactions (Blau, 
2003). Either the poem is interpreted as a nostalgic, heartwarming snapshot of a child's relationship with his father, or it is a sinister and potentially sickening portrayal of domestic violence. However, these views are not ours; they belong to the many people who have read the poem and written responses to it in blogs, homework, or term papers. The idea for using Roethke's poem in tertiary classes is not original. The Internet contains many examples of "model essays" on "My Papa's Waltz" (Brown \& Harrison, 1999). The strength of this poem in arousing a range of opinions in varied cultural contexts was of great interest to us, particularly as Hong Kong's recent education reforms have placed considerable weight on promoting personal responses to creative texts. It was also seen as a poem with interesting lexical and sentence structures that could be addressed in class. Since 2005, we have used this poem (and the others mentioned above) with multiple classes in three teacher training institutions in Hong Kong ranging from bachelor of education to master's degrees. The teaching procedures were similar in all cohorts and are presented below along with the teaching and learning outcomes.

\section{Teaching Strategy}

To elicit the personal response, we first distributed the poem and asked teachers to read it silently to themselves. Once they had done this, we invited them to underline a single line from the poem that they found interesting or important. This represented a critical point in the lesson. Once this had been completed, we asked the teachers to pair up and share with their partner the line that they had highlighted and the reason behind their choice. This allowed for an intersubjective approach where teachers discussed their chosen lines with others. The teachers spoke in pairs and then formed groups and were amazed to find that hardly any member of the group had chosen the same line. Even when teachers had occasionally chosen the same line, their reasons for underlining it always varied. We walked around and listened to the discussions.

At several stages in the reading process and group discussion stages, teachers sometimes asked for our input on the meaning of words and lines in the poem. At no point did we give the teachers any information about the poem or the poet, but we did address the issues of vocabulary and sentence structure, a concern for ELLs identified above. We recognized the danger of giving too much information to teachers at this point. Arguably, all literary texts can be seen as difficult because of unseen vocabulary or unusual sentence patterns, and it is understandable that teachers may then become helpful by providing all the meanings in order to allow their students access to the meaning of a text. However, we believed that the notion of difficulty should not be taken as a convenient excuse or reason for a purely linguistic or teacher-oriented approach. In choosing "My Papa's Waltz," we had seen 
that some vocabulary items had nothing to do with interpretation and so could be pre-taught at this stage. Words that had interpretive value, on the other hand, were not pre-taught. In other words, another criterion for selecting a poem would be the possibility of producing a selective glossary. Examples in this poem would include words with fixed meaning like countenance, buckle, or a phrase such as could not unfrown itself. These were all easily explained at this point in the lesson without shaping or revising a reader's own interpretation of the text as a whole. Yet words that might be ambiguously loaded such as beat and romp were deliberately left out of any explanation. Instead, by asking teachers to share their chosen lines with the class, the varied interpretations of lexical items such as beat, romp, clinging, and hung on like death could be negotiated by the group as a whole and not by us, the socalled authorities in the classroom. Thus the linguistic concerns of readers were addressed through discussion of meaning; their view of what certain words meant to them shaped their understanding of the whole poem.

In subsequent classes (after the first cohort), we started asking teachers to analyze some of the words that made them select certain lines in the poem, and this opened new channels of discussion and co-construction. We saw this as an ideal opportunity to examine their responses to lexical features; this strategy was aimed to help teachers to see the power of connotation and association and that fact that as readers, we often have varying interpretations of the same words. For example in "My Papa's Waltz," some teachers pointed to the "dark" terms that the poet uses: clinging, hung on like death, not easy, dizzy, beat time on my head, battered, scraped a buckle, and the hand that held my wrist. These were all cited as evidence of domestic abuse because of their negative connotations. Here we started to see teachers gain confidence in interpreting poems through contextual and linguistic clues. At the same time, other teachers identified many of the same words and phrases as being indicative of a positive tone in the poem. For example, teachers familiar with music saw another meaning behind the poet's phrase You beat time on my head and felt that this was actually helping the father and son to dance better. Some pointed to the term Papa in the title as indicative of a loving relationship and not one laced with violence. The whiskey, the battered ... knuckle and the buckle were all seen as evidence that the father was a hard-working man, possibly a farmer or blue-collar worker and not necessarily an alcoholic. Even the use of the verb waltzed when the son was taken to bed was seen as playful by some teachers, who noted the contrast with verbs such as dragged or marched, which would surely point toward coercion on the father's part. Indeed, one teacher claimed that the penultimate line surely pointed to abuse of the worst possible kind: sexual abuse. Some in the class gasped, and a few frowned as others saw this possibility for the first time during this teacher's elaboration of her response, which included reference to the words off to bed, which had been associated with sexual abuse. 
Indeed, it was when we started to elicit responses from the class that we truly felt the effect of this poem and technique on the teachers. One teacher, on being asked to describe the line he had chosen, gave an almost tearful response on how the final line of the poem (Still clinging to your shirt) had reminded him of his late father and how he wished he had spent more time with him when he was alive. Reference was also made to the sadly reported fact that many fathers in Hong Kong could have little quality time with their children because of work commitments and late hours. Immediately we started to see social and cultural issues emerging, although the poet had clearly not been writing about a Hong Kong family; teachers were making personal and social connections of their own.

We then decided to build this poem and the others mentioned above into subsequent courses, and the response from teachers regardless of age or experience has never failed to surprise us. Teachers at various stages of their careers have given us rich and varied responses to this poem, but it is noticeable that more experienced (i.e., inservice) teachers perhaps see the nostalgic, "happy" picture of the father playing boisterously with his child more often than many younger preservice teachers, who see a more violent picture. Does this perhaps reflect on modern society and values? This is an interesting social issue to raise in class as well, and it generates further discussion of the poem and its content. Thus from a single, self-contained activity designed to generate discussion in class, the poem and others like it have become a cornerstone of our teaching and have helped us to heighten teachers' awareness and confidence in how to encourage and promote their own as well as their students' personal responses to poetry. Over the years, we have collated teachers' responses and views, which in turn are used as prompts in lessons when we discuss the poem in greater detail. Some of the more positive responses to the poem include references to teachers' own families: "My father was not close to me; he didn't like to show his love" and "The first line reminds me of my father, but he used to smell of cigarettes and not whiskey." Some touched on the warmth of the setting: the father and son playing happily, with the mother showing mock disdain at the mess being created all around her. Yet from within the same cohorts, we encountered the negative perspective that has also been attached to this poem: "The father is an alcoholic," "If the mother tries to intervene she will be abused by the father," "the child is scared of the father and he is helpless," and from one rather disgusted teacher: "Take this away; it's horrible. I don't want to read it." This range of responses allowed teachers to see how personal reactions might be gleaned from their own students in a nonthreatening and participative manner. Teachers' opinions were valid because they had come from their own interpretations, and the opportunity to share their views on the poem in smaller groups before presenting them to us or each other had helped to alleviate learners' anxiety and broaden their understanding by uncovering others' views of the same piece. 
Our student teachers could see more clearly the connection between improving their own pedagogical effectiveness and developing their students' language proficiency, and it is worth summarizing some of the potential uses of the approach that we advocate. We maintain that readers' response should be promoted for the same reasons that Carter and Long (1991) promoted the teaching of literature: it can enhance language; it can lead to personal growth in students; and it can facilitate cultural awareness and appreciation of one's heritage. One advantage of this approach in terms of language-learning is that the text stimulates discussion that could apply to both oral and generallanguage lessons. "My Papa's Waltz," in particular, has also been a powerful tool in enabling learners to provide personal responses to a literary text. When asked why the same words in this poem are able to prompt myriad responses and interpretations in readers, many teachers in our courses believed that it had to do with personal experience and even their own culture. Of this there is no doubt; readers often saw themselves and their own families or childhood in the poem. Others saw social events and made connections between what they thought was happening in the poem and what they may have seen in the local news. It is surely no coincidence that in the last five years, Hong Kong has witnessed several tragic child abuse cases and that the issue of single-parent families has grown in line with concerns about migration, poverty, and social planning of new towns. Although these issues surfaced much earlier in Western cultures, Asia still lags behind in some ways, and many cases are complicated by social taboos and the strength of traditional values. The poem brought these important issues to the surface in a nonthreatening, nonjudgmental way, a point that we revisit in the following section.

\section{Evaluation}

At the beginning of this article, we refer to the difference between efferent and esthetic ways of experiencing a text. Noting how our teachers tended to place more emphasis on the former, we sought to activate awareness of their experiences while studying a text. We did not ask them what they thought the poem meant; rather, we simply asked them to identify one line in the poem that had impressed them. We made no judgment, and none was needed because the sharing in class illustrated the many perspectives that could be elicited from a single text common to all. According to course feedback, teachers found the methodology employed in class most helpful, and we noted a more positive attitude among teachers toward the use of readers' response in their own classrooms (see pedagogical implications below). Some dilemmas were raised, however. We were aware that "My Papa's Waltz" could elicit a range of emotions from our teachers from anger and sadness to feelings of happiness and warmth. It could well be that chosen texts may touch on sensitive areas that have affected readers in their lives: personal 
loss, broken homes, single-parent families, even child abuse. In such cases, an imaginary text becomes quite real, so in our classes we deliberately chose not to nominate individuals to answer, choosing instead to let our teachers initiate points. This was facilitated by our strategy of asking teachers to share their views with each other, first in pairs and then in groups, before eliciting responses. This co-construction of meaning among our individual teachers appeared to give them more confidence about speaking or answering questions in front of their peers and so to reduce anxiety in ELLs. As our teachers discussed their chosen lines in the poem, we circulated and monitored each group to see if reading the text had an emotional effect on any of the teachers. We could then speak with those individuals one on one immediately or at the end of the class. Although acknowledging that the implications for choice of texts are crucial, we still argue that the benefits of readers' responses will outweigh any negative factors. Choosing the right poem is never easy, but we have found some that have been effective, and these are discussed below.

\section{Pedagogical Implications}

Another poem that we use regularly is Jean Little's "Growing Pains," a narrative verse depicting a child's unhappy family situation. Like "My Papa's Waltz," it offers rich opportunities for reader-response activities and for accessing students' experiences and views of the world through their engagement with this poem. This is perhaps more appropriate for younger learners, as the speaker is clearly of a similar age to local secondary school students. Another strategy we have used in class with various poems has been to invite course participants to interact with a text by asking the speaker or poet questions. What did the reader want to know? What information was missing from the reading experience? What gaps in the context or story require filling? Such questions not only extend the reader's understanding of the possibilities in the poem, but also promote critical thinking skills by prompting teachers to construct further avenues into the poem. According to Rosenblatt (1978), this is the reader's "evoked work," and emerging through the original text, this evoked work is accorded interpretive authority. Although our courses primarily made use of poems, we also believe that similar responses would result if teachers used other texts such as stories, advertisements, and even pictures or paintings. Like "My Papa's Waltz," these texts and images have the potential to generate open and free discussion on a range of interpretations, each being accepted as valid or correct.

In our courses, teachers quickly understood this valuable pedagogical point, and further evidence was articulated in course assignments and observed classroom lessons when teachers used poems and other creative texts. In course assignments, we have asked our students to use other poems to articulate the reader-response theory, and on classroom visits we observed some teachers working with poems in local schools. It has been encouraging 
to see our teachers' development. We have seen them working with grades 8-13 with poems such as "Mirror" and "Mushrooms" (by Sylvia Plath), "Stopping by Woods" and "The Road Not Taken" by Robert Frost, as well as "Leisure" by William Henry Davies, which always strikes a chord in a busy city like Hong Kong. One teacher successfully used a television commercial (for a Canadian leather company) that did not reveal the target product until the end of the screening; by pausing to ask for predictions and viewpoints, she was able to elicit a range of responses from her learners. Other teachers combined poems with Reader's Theatre and Literature Circles to cater for learners' differences and to motivate students further. Teachers have told us that because their students were able to respond to these texts individually and collectively, they felt less threatened and concerned about the correct answer (although some students still asked for it at the end of lessons!). Some teachers claimed that the most difficult aspect for them was not intervening when students provided interesting and more imaginative answers. One teacher summed this up by saying, "It's very tempting to jump in and say 'yes, that's right,' but I don't want others to think their answers aren't welcome, so I have to stop myself from closing down the talk."

\section{Conclusion}

At the beginning of this article, we argue that attempts to integrate creative texts like poems into an ELL classroom are fraught with difficulties: students' concern about linguistic content as well as overall meaning, learners' anxiety, teachers' perceived lack of expertise in the subject, and students' concern about getting the right answer. Through our teacher training courses, we have seen teachers tackle these issues successfully by exploring and engaging with poems such as "My Papa's Waltz" and others, which has led to the emergence of their own responses and sensitivities toward the texts, as well as reduced anxiety about the linguistic content of poems. The challenge is to find more materials and pedagogies to allow for such activities in teachertraining courses and subsequently school contexts. However, we believe that these poems and this teaching approach will have an equal effect in other educational and social contexts because they place renewed emphasis on the reader as the authority in interpreting the poems, which elicits many personal and imaginative responses.

\section{The Authors}

Gary Harfitt is an assistant professor in the Faculty of Education, Hong Kong University. He has lived and worked in Hong Kong for more than 20 years and was previously a department head for English language at a local secondary school. His research areas include the incorporation of literature and language arts into ELT and the effectiveness of small-class teaching.

Blanche Chu is a senior instructor of English language at the Hong Kong Institute of Education. She has worked in this role for more than 10 years and has published in the area of cultural studies. She is completing her doctoral studies on the history of English literature in Hong Kong. 


\section{References}

Blau, S.D. (2003). The literature workshop: Teaching texts and their readers. Portsmouth, NH: Heinemann.

Brown, J.E., \& Harrison, L.G. (1999). Reader response to Roethke's My Papa's Waltz: Exploring different perspectives. In N. Karolides (Ed.), Reader response in secondary and college classrooms (pp. 327-339). Mahwah, NJ: Erlbaum.

Carlisle, A. (2000). Reading logs: An application of reader-response theory in ELT. ELT Journal, $54,12-19$.

Carter, R. (2007). Literature and language teaching 1986-2006: A review. International Journal of Applied Linguistics, 17, 3-13.

Carter, R., \& Long, M. (1991). Teaching literature. New York: Longman.

Curriculum Development Council. (2007). English language education key learning area: Literature in English, curriculum and assessment guide (Secondary 4-6). Hong Kong: Author and the Hong Kong Examinations and Assessment Authority..

Elliott, R. (1990). Encouraging reader-response to literature in ESL situations. ELT Journal, 44, 191-198.

Hirvela, A. (1996). Reader-response theory and ELT. ELT Journal, 50, 127-134.

Horwitz, E., Horwitz, M., \& Cope, J. (1986). Foreign language classroom anxiety. Modern Language Journal, 70, 125-132.

Karolides, N. (1999). Reader response in secondary and college classrooms, Mahwah, NJ: Erlbaum.

Rosenblatt, L. (1938). Literature as exploration. New York: Modern Language Association.

Rosenblatt, L. (1978). The reader, the text, the poem: The transactional theory of the literary work. Carbondale, IL: Southern Illinois University Press.

Showalter, E. (2003). Teaching literature. Oxford, UK: Blackwell.

Tsui, A.B.M. (1996). Reticence and anxiety in second language learning. In K. Bailey \& D. Nunan (Eds.), Voices from the language classroom (pp. 145-167). New York: Cambridge University Press. 